\title{
PENGGANTIAN KELAMIN BAGI TRANSEKSUAL DAN AKIBAT HUKUMNYA TERHADAP KEABSAHAN PERKAWINAN DITINJAU DARI UNDANG-UNDANG NOMOR 1 TAHUN 1974 TENTANG PERKAWINAN
}

\author{
Yeni Astutik \\ E-mail: yeniastutik6@student.uns.ac.id \\ Mahasiswa Fakultas Hukum Universitas Sebelas Maret \\ Anjar Sri Ciptorukmi Nugraheni \\ E-mail: anjarsri@staff.uns.ac.id \\ Dosen Fakultas Hukum Universitas Sebelas Maret
}

\begin{abstract}
This article aims to examine the ratification of changes in legal status and gender replacement procedures in population documents for transsexuals in Indonesia, as well as the legality of marriages for transsexuals in terms of Law Number 1 of 1974 concerning Marriage. The research method used is a type of normative legal research, with a qualitative approach. The legal materials used are primary and secondary legal materials, with data collection techniques used are literature study or document study techniques. Based on the results of the study, it was concluded that in Indonesia there are no specific rules regarding sex change, but for judges they cannot refuse a case because the law does not exist or is unclear. Regarding the procedure for changing sexes in population documents regulated in Act Number 23 of 2006 concerning Population Administration and Presidential Regulation of the Republic of Indonesia Number 25 of 2008 concerning Requirements and Procedures for Population Registration and Civil Registration. Then regarding the validity of marriage for transsexuals, from the six religions recognized by the government as the official religion in Indonesia, namely Islam, Christianity, Catholicism, Hinduism, Buddhism, and Confucianism, do not legalize a marriage carried out by parties, one of whom is a transsexual who has gone through Sex Reassignment Surgery.
\end{abstract}

Keywords: Sex Reassignment; Transsexual; Legality of Marriage.

\begin{abstract}
Abstrak
Artikel ini bertujuan untuk mengkaji pengesahan perubahan status hukum dan prosedur penggantian jenis kelamin di dokumen kependudukan bagi transeksual di Indonesia, serta keabsahan perkawinan bagi transeksual ditinjau dari Undang-Undang Nomor 1 Tahun 1974 tentang Perkawinan. Metode penelitian yang digunakan adalah jenis penelitian hukum normatif, dengan pendekatan kualitatif. Bahan hukum yang digunakan adalah bahan hukum primer dan sekunder, dengan teknik pengumpulan data yang digunakan adalah teknik studi kepustakaan atau studi dokumen. Berdasarkan hasil penelitian, disimpulkan bahwa di Indonesia belum ada aturan khusus mengenai penggantian jenis kelamin, namun bagi hakim tidak boleh menolak suatu perkara karena Undang-Undang tidak ada atau tidak jelas. Mengenai prosedur penggantian jenis kelamin di dokumen kependudukan diatur dalam UndangUndang Nomor 23 Tahun 2006 tentang Administrasi Kependudukan dan Peraturan Presiden Republik Indonesia Nomor 25 Tahun 2008 tentang Persyaratan dan Tata Cara Pendaftaran Penduduk dan Pencatatan Sipil. Kemudian mengenai keabsahan perkawinan bagi transeksual, dari keenam agama yang diakui pemerintah sebagai agama resmi di Indonesia yaitu Islam, Kristen, Katolik, Hindu, Buddha, dan Khonghucu, tidak mensahkan suatu perkawinan yang dilaksanakan oleh para pihak yang salah satunya seorang transeksual yang telah melalui operasi penggantian kelamin.
\end{abstract}

Kata Kunci: Penggantian Kelamin; Transeksual; Keabsahan Perkawinan. 


\section{A. Pendahuluan}

Pada hakikatnya Tuhan Yang Maha Esa menciptakan manusia terdiri dari dua jenis kelamin yaitu laki-laki dan perempuan, yang merupakan bagian manusia yang ditentukan secara biologis yang melekat pada dirinya (Risdalina, 2016: 41). Namun faktanya terdapat orang-orang mempunyai keraguan dalam menentukan jenis kelamin disebabkan tidak sesuainya jenis kelamin biologis dengan kondisi kejiwaan yang terjadi pada diri mereka. Mereka merasa terperangkap di tubuh yang salah misalnya seseorang yang terlahir dengan alat kelamin laki-laki tapi merasa bahwa dirinya perempuan dan sebaliknya.

Seiring dengan perkembangan ilmu pengetahuan dan teknologi khususnya di bidang kedokteran bagi mereka yang mengalami kondisi semacam itu dapat melakukan operasi penggantian kelamin (Sex Reassignment Surgery) sebagai suatu bentuk penanganan agar dapat sesuai dengan jiwanya. Operasi tersebut digunakan di seluruh dunia sebagai salah satu terapi untuk "dysphoria gender" atau "gender identity disorder" (Tomislav Bracanovic, 2016: 87). Orang- orang yang telah melakukan operasi penggantian kelamin (Sex Reassignment Surgery) disebut dengan istilah transeksual yaitu bentuk gangguan identitas gender (gender identity disorders). Istilah transeksual sendiri berasal dari Bahasa Inggris Trans dan sexual, Trans berarti peralihan atau perpindahan sedangkan sexual diartikan dengan klasifikasi biologis tubuh, fisiologis sebagai laki-laki atau perempuan biasanya ditentukan oleh organ seks eksternal, seks internal dan organ reproduksi, kromosom, hormon dan perkembangan seksual sekunder pada masa pubertas (Gibtiah, $2016: 350$ ).

Bagi seorang transeksual yang telah mengubah jenis kelaminnya harus memohonkan kepada pengadilan guna mendapatkan pengesahan atas perubahan kelamin. Setelah mendapatkan pengesahan atas perubahan kelamin dari negara berdasarkan Penetapan pengadilan, maka dapat mengajukan permohonan untuk mengubah identitas baik nama maupun jenis kelamin dalam dokumen kependudukan melalui prosedur yang telah ditentukan. Perubahan identitas tersebut berupa perubahan nama dan jenis kelamin baik dalam Kartu Tanda Penduduk (KTP), Kartu Keluarga (KK) maupun akta kelahiran.

Bagi seorang transeksual yang telah mendapat pengesahan dari pengadilan negeri serta telah mengubah identitasnya dalam dokumen kependudukan, seharusnya tidak terjadi dan timbul suatu permasalahan apabila seorang transeksual melaksanakan perkawinan. Namun demikian bahwa secara jelas keabsahan perkawinan menurut Undang-Undang Nomor 1 Tahun 1974 tentang Perkawinan (selanjutnya disebut UUP) tidak hanya melihat pada hukum negara, melainkan juga hukum agama. Hal sebagaimana dinyatakan dalam Pasal 2 ayat (1) UUP, yaitu Perkawinan adalah sah apabila dilakukan menurut hukum masing-masing agama dan kepercayaannya itu. Mengingat dalam Pasal 2 ayat (1) UUP bahwa perkawinan adalah sah apabila dilakukan menurut agama dan kepercayaan, maka pada artikel ini penulis memberi batasan hanya mengenai keabsahan perkawinan bagi transeksual ditinjau dari agama. Berdasarkan hal tersebut, saat ini Indonesia memiliki 6 (enam) agama yang diakui pemerintah sebagai agama resmi yaitu Islam, Kristen, Katolik, Hindu, Buddha, dan Khonghucu.

Berdasarkan uraian di atas, maka artikel ini membahas mengenai pengesahan perubahan status hukum dan prosedur penggantian jenis kelamin bagi transeksual di Indonesia, serta keabsahan perkawinan bagi transeksual ditinjau dari Undang-Undang Nomor 1 Tahun 1974 tentang Perkawinan.

\section{B. Metode Penelitian}

Jenis penelitian yang digunakan dalam penyusunan penulisan hukum ini adalah penelitian hukum normatif atau penelitian kepustakaan dengan menggunakan sumber bahan hukum primer dan sekunder. Sifat penelitian yang digunakan dalam penyusunan penulisan hukum ini adalah penelitian deskriptif, penelitian untuk menyampaikan data yang seteliti mungkin melalui gambaran tentang gejala tertentu. Pendekatan penulisan hukum ini menggunakan pendekatan kualitatif 
yaitu pendekatan dengan mendasarkan pada data-data yang dinyatakan dalam bentuk tertulis, yang diteliti dan dipelajari sebagai suatu yang utuh. Teknik pengumpulan bahan hukum dalam penelitian ini adalah studi kepustakaan atau studi dokumen yaitu dilakukan dengan cara mangkaji, dan mempelajari literatur, buku-buku, peraturan perundang-undangan, dokumen laporan, arsipan hasil penelitian, serta tulisan-tulisan yang berhubungan dengan masalah yang menjadi objek penelitian. Teknik analisis bahan hukum yang digunakan dalam penelitian ini adalah metode kualitatif yaitu dengan mengumpulkan data, mengkualifikasikan kemudian menghubungkan teori yang berhubungan dengan masalah dan akhirnya menarik kesimpulan untuk menentukan hasil (Soerjono Soekanto, 2007: 43).

\section{Hasil Penelitian dan Pembahasan}

\section{Pengesahan Perubahan Status Hukum dan Prosedur Penggantian Jenis Kelamin di} Dokumen Kependudukan bagi Transeksual di Indonesia

\section{a. Pengesahan Perubahan Status Hukum bagi Transeksual di Indonesia}

Transeksual atau dalam bahasa Inggris disebut Transsexual adalah seseorang yang memiliki salah satu jenis kelamin antara laki-laki atau perempuan namun identifikasi karakteristik pribadi dan psikososialnya menyerupai lawan jenisnya dan memilih untuk hidup sebagai anggota dari lawan jenis dengan melakukan operasi penggantian kelamin (Sex Reassignment Surgery).

Bagi seorang transeksual yang telah mengubah jenis kelaminnya harus memohonkan kepada pengadilan guna mendapatkan penetapan dari pengadilan. Penetapan pengadilan ini difungsikan untuk mendapatkan pengesahan atas perubahan kelamin. Perlu diketahui bahwa, hingga saat ini di Indonesia belum ada aturan khusus mengenai penggantian jenis kelamin, namun bagi hakim tidak boleh menolak suatu perkara karena Undang-Undang tidak ada atau tidak jelas. Hal sebagaimana diatur dalam Pasal 10 ayat (1) UndangUndang Nomor 48 Tahun 2009 tentang Kekuasaan Kehakiman yang menyatakan bahwa, Pengadilan dilarang menolak untuk memeriksa, mengadili, dan memutus suatu perkara yang diajukan dengan dalih bahwa hukum tidak ada atau kurang jelas, melainkan wajib untuk memeriksa dan mengadilinya.

Di Indonesia sendiri sejak tahun 1973 telah ada penetapan pengadilan mengenai permohonan penggantian kelamin yaitu Penetapan Pengadilan Nomor 546/Pdt P/1973/ PN JKT Sel dan Brt. Penetapan tersebut merupakan ketetapan terhadap Iwan Robyanto Iskandar yang telah menjalani operasi penggantian kelamin (Sex Reassignment Surgery) di Singapura pada tanggal 28 Juni 1973 dan kemudian mengganti namanya menjadi Vivian Rubiyanti Iskandar. Ketetapan terhadap Iwan Robyanto Iskandar menjadi suatu constante jurisprudentie, karena selalu diikuti oleh hakim lain untuk menetapkan kasus yang serupa (Fred Ameln, 1991: 31).

Pada kurun waktu yang belum lama ini Pengadilan Negeri Surakarta mengabulkan permohonan yang sama dan ditetapkan dalam Penetapan Pengadilan Negeri Surakarta Nomor 87/Pdt P/2016/PN Skt. Penetapan tersebut merupakan ketetapan terhadap permohonan yang diajukan oleh Romandito Haryo Prabowo dengan jenis kelamin lakilaki yang telah menjalani operasi penggantian kelamin (Sex Reassignment Surgery) di Thailand dan kemudian mengganti namanya menjadi Meiradita Khairunnisa dengan jenis kelamin perempuan. Berdasarkan Penetapan Pengadilan Negeri Surakarta Nomor 87/ Pdt P/2016/PN Skt dalam pertimbangan hukumnya hakim mendasarkan pada 2 (dua) aspek yaitu aspek hukum dan aspek medis. Selain itu hakim tidak meninjau hukum dari sisi agama Pemohon, sehingga aspek moralitas yaitu menyangkut nilai keagamaan tidak menjadi pertimbangan dalam membuat ketetapan tersebut. 


\section{b. Prosedur Penggantian Jenis Kelamin di Dokumen Kependudukan bagi Transeksual di Indonesia}

Pada dasarnya, di Indonesia belum ada aturan khusus mengenai penggantian jenis kelamin bagi seseorang yang telah melakukan operasi kelamin. Akan tetapi, untuk memberikan perlindungan, pengakuan, penentuan status pribadi dan status hukum setiap peristiwa kependudukan dan peristiwa penting yang dialami oleh penduduk Indonesia dan Warga Negara Indonesia yang berada di luar wilayah Negara Kesatuan Republik Indonesia, telah diterbitkan Undang-Undang Nomor 23 Tahun 2006 tentang Administrasi Kependudukan (selanjutnya disebut UU Adminduk).

Mengenai penggantian jenis kelamin berkaitan erat dengan Pasal 56 ayat (1) UU Adminduk beserta penjelasannya. Dalam Pasal 56 ayat (1) UU Adminduk menyebutkan bahwa, Pencatatan peristiwa penting lainnya dilakukan oleh Pejabat Pencatatan Sipil atas permintaan Penduduk yang bersangkutan setelah adanya penetapan pengadilan negeri yang telah memperoleh kekuatan hukum tetap. Sedangkan yang dimaksud dengan "peristiwa penting lainnya" dijelaskan dalam Penjelasan Pasal 56 ayat (1) UU Adminduk yang meyatakan bahwa, yang dimaksud dengan "Peristiwa Penting lainnya" adalah peristiwa yang ditetapkan oleh pengadilan negeri untuk dicatatkan pada Instansi Pelaksana, antara lain perubahan jenis kelamin.

Berdasarkan Pasal 56 ayat (1) UU Adminduk, jika benar seseorang telah mengubah jenis kelaminnya harus memohonkan kepada pengadilan guna mendapatkan penetapan dari pengadilan. Penetapan pengadilan ini difungsikan untuk mendapatkan pengesahan atas perubahan kelamin. Setelah mendapatkan pengesahan atas perubahan kelamin dari negara berdasarkan Penetapan pengadilan tersebut, maka dapat mengajukan permohonan untuk mengubah identitas baik nama maupun jenis kelamin dalam dokumen kependudukan. Sebagai tindak lanjut dari aturan dalam UU Adminduk telah diterbitkan Peraturan Presiden Republik Indonesa Nomor 25 Tahun 2008 tentang Persyaratan dan Tata Cara Pendaftaran Penduduk dan Pencatatan Sipil (selanjutnya disebut Perpres 25 Tahun 2008). Serupa dengan aturan dalam Pasal 56 ayat (1) UU Adminduk tentang pencatatan peristiwa penting lainnya, dalam Pasal 97 ayat (2) Perpres 25 Tahun 2008 ini juga disebut bahwa peristiwa penting lainnya yang dimaksud antara lain adalah perubahan jenis kelamin.

Mengenai perubahan nama dapat dicatatkan dalam pencatatan sipil, sebagaimana diatur dalam Pasal 52 UU Adminduk yang menyatakan bahwa:

(1) Pencatatan perubahan nama dilaksanakan berdasarkan penetapan pengadilan negeri tempat pemohon;

(2) Pencatatan perubahan nama sebagaimana dimaksud pada ayat (1) wajib dilaporkan oleh Penduduk kepada Instansi Pelaksana yang menerbitkan akta Pencatatan Sipil paling lambat 30 (tiga puluh) hari sejak diterimanya salinan penetapan pengadilan negeri oleh Penduduk;

(3) Berdasarkan laporan sebagaimana dimaksud pada ayat (2), Pejabat Pencatatan Sipil membuat catatan pinggir pada register akta Pencatatan Sipil dan kutipan akta Pencatatan Sipil.

Kemudian tatacara pencatatan perubahan nama pada pencatatan sipil dijelaskan dalam Pasal 93 Perpres 25 Tahun 2008, yaitu:

(1) Pencatatan pelaporan perubahan nama dilakukan pada Instansi Pelaksana atau UPTD Instansi Pelaksana yang menerbitkan Akta Pencatatan Sipil.

(2) Pencatatan perubahan nama sebagaimana dimaksud pada ayat (1) dilakukan dengan memenuhi syarat berupa:

a. salinan penetapan pengadilan negeri tentang perubahan nama; 
b. Kutipan Akta Catatan Sipil;

c. Kutipan Akta Perkawinan bagi yang sudah kawin;

d. fotokopi KK; dan

e. fotokopi KTP.

(3) Pencatatan pelaporan perubahan nama sebagaimana dimaksud pada ayat (1), dilakukan dengan tata cara:

a. Pemohon mengisi dan menyerahkan Formulir Pelaporan Perubahan Nama dengan melampirkan persyaratan sebagaimana dimaksud pada ayat (2) kepada Instansi Pelaksana atau UPTD Instansi Pelaksana;

b. Pejabat Pencatatan Sipil pada Instansi Pelaksana atau UPTD Instansi Pelaksana membuat catatan pinggir pada register akta catatan sipil dan kutipan akta catatan sipil;

c. Instansi Pelaksana atau UPTD Instansi Pelaksana sebagaimana dimaksud pada huruf b merekam data perubahan nama dalam database kependudukan.

Sedangkan mengenai perubahan status seseorang dalam hal ini perubahan jenis kelamin, diatur di dalam Pasal 56 UU Adminduk yaitu:

(1) Pencatatan Peristiwa Penting lainnya dilakukan oleh Pejabat Pencatatan Sipil atas permintaan Penduduk yang bersangkutan setelah adanya putusan pengadilan negeri yang telah memperoleh kekuatan hukum tetap.

(2) Pencatatan Peristiwa Penting lainnya sebagaimana dimaksud pada ayat (1) paling lambat 30 (tiga puluh) hari setelah diterimanya salinan penetapan pengadilan.

(3) Ketentuan lebih lanjut mengenai persyaratan dan tata cara pencatatan Peristiwa Penting lainnya diatur dalam Peraturan Presiden.

Menurut penjelasan Pasal 56, yang dimaksud dengan peristiwa penting lainnya adalah peristiwa yang ditetapkan oleh pengadilan negeri untuk dicatatkan pada Instansi Pelaksana, antara lain perubahan jenis kelamin.

Pengaturan mengenai tata cara pencatatan peristiwa penting lainnya dalam hal ini perubahan jenis kelamin tertuang di dalam Pasal 97 ayat (4) Perpres 25 Tahun 2008, yaitu:

(1) Pencatatan pelaporan peristiwa penting lainnya dilakukan oleh pejabat Pencatatan Sipil pada Instansi Pelaksana atau UPTD Instansi Pelaksana tempat terjadinya peristiwa penting lainnya.

(2) Peristiwa penting lainnya sebagaimana dimaksud pada ayat (1) antara lain perubahan jenis kelamin.

(3) Pencatatan peristiwa penting lainnya sebagaimana dimaksud pada ayat (1) dilakukan dengan memenuhi syarat berupa:

a. Penetapan pengadilan mengenai peristiwa penting lainnya;

b. KTP dan KK yang bersangkutan; dan

c. Akta Pencatatan Sipil yang berkaitan peristiwa penting lainnya.

(4) Pencatatan peristiwa penting lainnya sebagaimana dimaksud pada ayat (1), dilakukan dengan tata cara:

a. Pelapor mengisi dan menyerahkan Formulir Pencatatan Peristiwa Penting Lainnya dengan melampirkan persyaratan sebagaimana dimaksud pada ayat (2) kepada Instansi Pelaksana atau UPTD Instansi Pelaksana;

b. Pejabat Pencatatan Sipil pada Instansi Pelaksana atau UPTD Instansi Pelaksana melakukan verifikasi dan validasi berkas pelaporan peristiwa penting lainnya, dan mencatat serta merekam dalam register peristiwa penting lainnya pada database kependudukan; 
c. Pejabat Pencatatan Sipil pada Instansi Pelaksana atau UPTD Instansi Pelaksanamembuat catatan pinggir pada Register Akta Pencatatan Sipil dan Kutipan Akta Pencatatan Sipil.

Mengenai akta kelahiran tidak diganti dengan akta yang baru atau adanya penerbitan akta kelahiran yang baru. Namun berdasarkan Pasal 52 UU Adminduk jo. Pasal 93 Perpres 25 Tahun 2008 dan Pasal 56 UU Adminduk jo. Pasal 97 Perpres 25 Tahun 2008, akta pencatatan sipil yang berkaitan dengan perubahan nama dan jenis kelamin akan diberikan catatan pinggir oleh Instansi Pelaksana. Akta pencatatan sipil yang dimaksud salah satunya adalah akta kelahiran.

Jadi akta baik di dalam kutipan akta maupun dalam register akta tidak berubah namun adanya penambahan yaitu adanya catatan pinggir yang menjelaskan mengenai peristiwa penting tersebut. Mengenai catatan pinggir itu sendiri termuat dalam Penjelasan Pasal 47 UU Adminduk yang menyatakan bahwa, Yang dimaksud dengan catatan pinggir adalah catatan mengenai perubahan status atas terjadinya Peristiwa Penting dalam bentuk catatan yang diletakkan pada bagian pinggir akta atau bagian akta yang memungkinkan (di halaman/bagian muka atau belakang akta) oleh Pejabat Pencatatan Sipil.

Setelah semua prosedur terlewati maka seseorang yang telah melakukan operasi kelamin baik operasipenggantiankelamin (SexReassignment Surgery)maupunoperasi penyempurnaan kelamin memiliki identitas baru yang tercantum dalam dokumen kependudukan. Dokumen kependudukan tersebut sangat diperlukan sebagai suatu penegasan status seseorang yaitu apakah laki-laki atau perempuan, karena dari penentuan status demikian sangat diperlukan apabila seseorang ingin melangsungkan perkawinan, menjelaskan status kewarisan, dan identitas pekerjaan, serta lain-lainnya untuk kebutuhan hidup sebagaimana seorang warganegara.

2. Keabsahan Perkawinan bagi Transeksual ditinjau dari Undang-Undang Nomor 1 Tahun 1974 tentang Perkawinan

Di Indonesia perkawinan diatur dalam UUP. Dalam Pasal 1 UUP mengenai pengertian perkawinan dijelaskan bahwa, Perkawinan adalah ikatan lahir batin antara seorang pria dan seorang wanita sebagai suami istri dengan tujuan membentuk keluarga atau rumah tangga yang bahagia dan kekal berdasarkan Ketuhanan Yang Maha Esa.

Kemudian terkait dengan keabsahan suatu perkawinan dinyatakan dalam Pasal 2 ayat (1) UUP yaitu Perkawinan adalah sah apabila dilakukan menurut hukum masing-masing agama dan kepercayaannya itu. Keabsahan suatu perkawinan dalam Pasal 2 ayat (1) Undang-Undang Nomor 1 Tahun 1974 tersebut dipertegas lagi dalam penjelasan Pasal 2 ayat (1) Undangundang Nomor 1 Tahun 1974 yang menyatakan bahwa, dengan perumusan pada Pasal 2 ayat (1) ini, tidak ada Perkawinan di luar hukum masing-masing agamanya dan kepercayaannya itu, sesuai dengan Undang-undang Dasar 1945. Yang dimaksud dengan hukum masing- masing agamanya dan kepercayaannya itu termasuk ketentuan perundang-undangan yang berlaku bagi golongan agamanya dan kepercayaannya itu sepanjang tidak bertentangan atau tidak ditentukan lain dalam undang-undang ini.

Mengacu pada keabsahan perkawinan adalah sah apabila dilaksanakan menurut hukum agama, saat ini Indonesia memiliki 6 (enam) agama yang diakui pemerintah sebagai agama resmi yaitu Islam, Kristen, Katolik, Hindu, Buddha, dan Khonghucu. Hal sebagaimana termuat dalam Penjelasan Atas Penetapan Presiden Nomor 1 Tahun 1965 terhadap Penyalahgunaan dan/atau Penodaan Agama Pasal 1 yang menyatakan bahwa, Agama-agama yang dipeluk oleh penduduk di Indonesia ialah Islam, Kristen, Katolik, Hindu, Buddha dan Khong Hu Chu (Confusius).

Selanjutnya berdasarkan pengertian perkawinan sebagaimana tercantum dalam Pasal 1 UUP, mengisyaratkan bahwa perkawinan hanya dapat dilakukan oleh seorang pria dengan 
seorang wanita. Bagi seorang transseksual yang telah mendapatkan pengesahan pengadilan atas perubahan jenis kelaminnya serta telah mengubah identitasnya dalam dokumen kependudukan, seharusnya tidak timbul dan terjadi permasalahan terkait perkawinan karena sudah adanya penegasan status apakah pria atau wanita. Namun bagaimana akibat hukumnya terhadap keabsahan perkawinan. Sebelumnya telah diketahui bahwa terkait dengan keabsahan suatu perkawinan, tidak lepas kaitannya dengan hukum agama. Maka berdasarkan hal tersebut muncul pertanyaan apakah dari keenam agama yang diakui pemerintah sebagai agama resmi di Indonesia yaitu Islam, Kristen, Katolik, Hindu, Buddha dan Khonghucu mensahkan perkawinan yang dilaksanakan oleh transeksual.

Berdasarkan hal tersebut di atas, berikut uraian mengenai keabsahan perkawinan yang dilaksanakan oleh para pihak yang salah satunya merupakan seorang transeksual ditinjau dari keenam agama yang diakui pemerintah sebagai agama resmi di Indonesia, diantaranya yaitu:

\section{a. Agama Islam}

Permasalahan perubahan dan penyempurnaan kelamin yang muncul di era modern ini belum dikenal dalam abad klasik dan pertengahan, sehingga pembahasan hukumnya tidak dijumpai dalam kitab-kitab figh klasik. Pembahasan operasi kelamin baru dijumpai dalam hukum Islam kontemporer sejalan dengan perkembangan ilmu pengetahuan dan teknologi (Arisman, 2019: 66).

Terhadap kasus perubahan dan penyempurnaan kelamin, Majelis Ulama Indonesia (MUI) telah mengeluarkan 2 (dua) fatwa yang mengaturnya, yaitu:

a. Fatwa Majelis Ulama Indonesia Tentang Operasi Perubahan/Penyempurnaan Kelamin (Musyawarah Nasional II nomor 05/Kep./Munas II/MUI/1980 tanggal 1 Juni tahun 1980)

b. Fatwa Majelis Ulama Indonesia Nomor 03/MUNASVIII/MUI/2010 tentang Pengubahan dan Penyempurnaan Jenis Kelamin.

Berdasarkan Fatwa Majelis Ulama Indonesia (MUI) di atas, mengenai perkawinan yang dilaksanakan bagi para pihak yang salah satunya telah melalui operasi penggantian kelamin (Sex Reassignment Surgery) maka perkawinannya tidak sah atau haram menurut pandangan Islam. Karena pada prinsipnya ia telah melakukan perkawinan dengan orang yang mempunyai jenis kelamin yang sama dengan dirinya atau dianggap nikah sesama jenis yang tergolong dosa besar. Sebagaimana berdasarkan Fatwa Majelis Ulama Indonesia (MUI) bahwa, apabila seseorang melakukan operasi perubahan atau penggantian kelamin maka status jenis kelaminnya adalah sama dengan jenis kelamin sebelum dilakukannya operasi kelamin.

\section{b. Agama Kristen}

Menurut pandangan Kristen transeksualitas tidak dapat dibenarkan di hadapan Allah karena melanggar banyak prinsip yang ada dalam Firman Tuhan. Mengenai Perkawinan transeksual dalam pandangan Kristen dianggap sebagai hubungan antara sesama jenis yang disebut dengan homoseksual, meskipun mereka mengubah jenis kelamin luarnya. Allah di dalam wahyu-Nya (Alkitab) baik dalam Perjanjian Lama maupun dalam Perjanjian Baru, sangat jelas tidak suka atau bahkan menentang perilaku homoseksual. Dalam teksteks perjanjian lama homoseksual dipandang secara sangat negatif (Im. 18:22; Kej. 19). Demikian pula dalam teks-teks perjanjian baru memandang homoseksual sebagai suatu perilaku seksual yang menyimpang (Rom. 1:26-27; 1 Kor. 6:9-11; 1 Tim. 1:10 dan Yud. 1:7). Perilaku homoseksual adalah tindakan yang sangat berdosa karena tindakan tersebut menentang apa yang sudah ditetapkan oleh Allah bahwa hubungan seksual seharusnya adalah heteroseksual, antara laki-laki dan perempuan, bukan hubungan sesama jenis (Sjanette Eveline, 2019: 59). 


\section{c. Agama Katolik}

Transeksual dapat dikatakan sebagai suatu hal yang alamiah atau wajar yang bisa terjadi dalam proses kelahiran atau pertumbuhan manusia, Gereja Katolik mengikuti ajaran Yesus memaklumi hak tersebut. Namun demikian, sesuai dengan Katekismus Gereja Katolik Nomor 369, operasi ganti kelamin tidak dibenarkan pada perilaku penyimpangan orientasi seksual yang diakibatkan hanya karena dorongan psikologis semata (Zenny Natasia Lianto, 2018: 258). Kemudian, bagi seorang transeksual yang telah mejalankan operasi ganti kelamin dikarenakan hanya mengikuti dorongan psikologisnya saja tidak akan pernah bisa secara sah menerima sakramen perkawinan. Kerena walaupun mereka telah melakukan operasi ganti kelamin dan status mereka telah berubah secara hukum, namun status mereka sebagai laki-laki atau perempuan tetaplah sama di mata Gereja seperti sebelum mereka menjalankan operasi ganti kelamin. Status identitas seksual mereka tetaplah sama untuk selamanya seperti yang telah dianugerahkan Allah kepada mereka sejak lahir. Mereka tidak akan pernah dapat melangsungkan perkawinan secara sah kerena mereka tidak akan bisa mewujudkan cinta kasih suami istri secara sempurna dan tidak akan bisa memiliki anak (Zenny Natasia Lianto, 2018: 256).

\section{d. Agama Hindu}

Mengenai perkawinan menurut agama Hindu, perkawinan (wiwaha) adalah ikatan seorang pria dan wanita sebagai suami isteri untuk mengatur hubungan seks yang layak guna mendapatkan keturunan anak pria yang akan menyelamatkan arwah orang tuanya dari neraka, yang dilangsungkan dengan upacara ritual menurut agama Hindu Weda Smerti (G. Pudja, dalam Hilman Hadikusuma, 1990: 12). Dalam agama Hindu tidak menghendaki perkawinan bagi transeksual dikarenakan perkawinan tersebut tidak sesuai dengan tujuan perkawinan dalam agama Hindu yaitu dalam hal mendapatkan keturunan. Karena seseorang yang telah melakukan operasi penggantian kelamin (Sex Reassignment Surgery) tidak mungkin mendapatkan keturunan secara normal, meskipun alat kelamin luar yang merupakan bagian alat reproduksi pada manusia bisa diubah.

Selain hal tersebut dapat diasumsikan bahwa mengenai perkawinan yang dilaksanakan oleh para pihak yang salah satunya seorang transeksual merupakan hubungan antara sesama jenis atau disebut sebagai homoseksual. Dikarenakan seseorang yang melakukan operasi penggantian kelamin (Sex Reassignment Surgery) yang diubah adalah bentuk dan penampilan bagian luar dari alat kelaminnya saja. Dalam agama Hindu tidak menerima perkawinan sesama jenis walaupun tidak dibahas secara rinci namun agama ini membahas tentang karma yang akan mereka dapatkan balasannya atas perbuatan yang dilakukan karena hal itu merupakan penyimpangan dari nilai-nilai moral (Syafi'in Mansur, 2017: 47).

\section{e. Agama Buddha}

Ajaran Buddha menguasai jenis kelamin ketiga yang termuat dalam Vinaya Pitaka yang merupakan salah satu bagian dari Tripitaka (kitab suci Buddha). Salah satu teks yang ditulis dalam Vinaya Pitaka ialah aturan mengenai seks dan gender. Dalam teks Vinaya Pitaka, gender dibagi menjadi empat yakni laki-laki, perempuan, hemafrodit (intersex) dan homosexual. Kemudian ketidaksamaan identitas gender seseorang terhadap jenis kelamin yang dimilikinya disebut transgender. Menurut pandangan agama Buddha, kaum transgender sebagian besar sering mengalami tekanan batin dan tidak mempunyai kebebasan dalam pergaulan, maka tidak ada salahnya kaum transgender itu melakukan operasi penggantian kelamin (Sex Reassignment Surgery). Hal ini tidak bertentangan dengan Vinaya (sila), karena operasi penggantian kelamin itu dilakukan untuk membebaskan diri dari tekanan batin dan tidak merugikan makhluk lainnya. 
Bagi transgender yang telah melakukan operasi penggantian kelamin (Sex Reassignment Surgery), maka disebut sebagai transeksual. Kemudian apabila seorang transeksual menikah dengan seseorang yang jenis kelaminnya berlawanan dengan jenis kelaminnya setelah melakukan operasi penggantian kelamin (Sex Reassignment Surgery), maka pernikahannya merupakan pernikahan sesama jenis yang termasuk ke dalam perilaku homoseksual. Dalam agama Buddha tidak mengutuk dan menghukum homoseksual atau transgender dan tidak keras pula terhadap pernikahan sesama jenis. Namun demikian, sebagian besar para bhikkhu (biarawan Buddha) menolak pernikahan sesama jenis yang termasuk ke dalam perilaku homoseksual. Bhikkhu Uttamo Mahathera, seperti yang dikutip dari situs Bodhi Buddhist Centre Indonesia, berpendapat bahwa perilaku homoseksual termasuk melanggar sila ke-3 dalam Pancasila Buddhis, yaitu melakukan perbuatan asusila yang maksudnya adalah melakukan pemuasan nafsu indriawi yang menyimpang.

\section{f. Agama Khonghucu}

Mengenai perkawinan dalam ajaran Khonghucu adalah antara laki-laki dan perempuan, pertautan antara Khian dan Khun-lah yang melahirkan keturunan anak manusia dan ini adalah Firman Tuhan atau Kodrat (Tim Matakin, 2012: 80). Berdasarkan hal tersebut Uung Sendana sebagai wakil Majelis Tinggi Agama Khonghucu Indonesia (MATAKIN) menyatakan penolakan terhadap LGBT (Lesbian, Gay, Biseksual, Transgender) yang termasuk dalam perilaku homoseksual. Dikaitkan dengan transeksual, sebagaimana diketahui bahwa pada dasarnya apabila dua pihak melaksanakan perkawinan dan salah satunya merupakan seorang transeksual maka perkawinan tersebut dianggap sebagai perkawinan sesama jenis atau homoseksual. Selain itu perkawinan bagi transeksual juga tidak sesuai dengan perkawinan dalam ajaran Khonghucu yaitu mengenai keturunan. Sebagaimana telah diketahui bahwa seorang transeksual yang telah melalui operasi penggantian kelamin (Sex Reassignment Surgery) tidak mungkin lagi bisa mempunyai keturunan, walaupun pada dasarnya tidak semua perkawinan yang dilakukan oleh pria dan wanita akan menghasilkan keturunan.

Berdasarkan uraian di atas dapat disimpulkan bahwa dari keenam agama yang diakui pemerintah sebagai agama resmi di Indonesia yaitu Islam, Kristen, Katolik, Hindu, Buddha, dan Khonghucu, tidak mensahkan suatu perkawinan yang dilaksanakan oleh para pihak yang salah satunya telah melalui operasi penggantian kelamin (Sex Reassignment Surgery) atau disebut sebagai transeksual. Keenam agama tersebut tidak membenarkan bahkan melarang perkawinan semacam itu dikarenakan tergolong dalam perilaku homoseksual serta tidak sesuai dengan tujuan perkawinan berdasarkan pandangan beberapa agama.

\section{Simpulan}

Di Indonesia belum ada aturan khusus mengenai penggantian jenis kelamin, namun bagi hakim tidak boleh menolak suatu perkara karena Undang-Undang tidak ada atau tidak jelas. Hal sebagaimana diatur dalam Pasal 10 ayat (1) Undang-Undang Nomor 48 Tahun 2009 tentang Kekuasaan Kehakiman. Berdasarkan Penetapan Pengadilan Negeri Surakarta Nomor 87/ Pdt P/2016/PN Skt dalam pertimbangan hukumnya hakim mendasarkan pada 2 (dua) aspek yaitu aspek hukum dan aspek medis. Aspek moralitas yaitu menyangkut nilai keagamaan tidak menjadi pertimbangan hakim dalam membuat ketetapan tersebut. Kemudian mengenai prosedur penggantian jenis kelamin di dokumen kependudukan diatur dalam UU Adminduk dan Perpres 25

Tahun 2008. Mengenai perubahan nama diatur dalam Pasal 52 UU Adminduk jo. Pasal 93 Perpres 25 Tahun 2008. Sedangkan mengenai perubahan jenis kelamin diatur dalam Pasal 56 UU Adminduk jo. Pasal 97 Perpres 25 Tahun 2008. Pada akta kelahiran baik dalam kutipan akta maupun dalam register akta, nama dan jenis kelamin tidak berubah namun adanya penambahan yaitu adanya catatan pinggir yang menjelaskan mengenai peristiwa penting dalam hal ini 
perubahan jenis kelamin. Sedangkan mengenai perkawinan yang dilaksanakan oleh para pihak yang salah satunya seorang transeksual tidak diakui keabsahannya oleh keenam agama yang diakui pemerintah sebagai agama resmi di Indonesia yaitu Islam, Kristen, Katolik, Hindu, Buddha, dan Khonghucu. Keenam agama tersebut tidak membenarkan bahkan melarang perkawinan semacam itu dikarenakan tergolong dalam perilaku homoseksual serta tidak sesuai dengan tujuan perkawinan berdasarkan pandangan beberapa agama.

\section{E. Saran}

Berdasarkan hasil penelitian dan pembahasan yang telah peneliti lakukan, peneliti menyarankan kepada hakim dalam membuat ketetapan atas permohonan ganti kelamin hendaknya dalam pertimbangan hukumnya juga mendasarkan atas aspek moralitas dengan meninjau hukum dari sisi agama Pemohon. Hal ini dengan alasan agar hakim dapat memberikan putusan yang sesuai dengan nilai-nilai yang hidup dalam masyarakat. Kemudian bagi pemerintah alangkah baiknya membentuk suatu peraturan perundang-undangan mengenai penggantian jenis kelamin akibat telah melakukan operasi kelamin. Selain itu penulis juga menyarankan kepada pelaku transeksual bahwa perlu dipertimbangkan lebih matang mengenai tindakan yang dilakukan setelah melakukan operasi penggantian kelamin (Sex Reassignment Surgery), dalam hal ini yaitu melaksanakan perkawinan. Karena hal tersebut mempunyai akibat hukum menyangkut keabsahan perkawinan.

\section{F. Daftar Pustaka}

\section{Buku}

Fred Ameln. 1991. Kapita Selekta Hukum Kedokteran. Jakarta: Grafikatama Jaya. Cet. Ke-1. Hilman Hadikusuma. 1990. Hukum Perkawinan Indonesia. Bandung: Manda Maju. Cet. 1.

I Made Titip. 2003. Veda Sabda Suci Pedoman Praktis Kehidupan. Surabaya: Penerbit Paramita.

Soerjono Soekanto. 2007. Pengantar Penelitian Hukum. Cet III. Jakarta: Penerbit Universitas Indonesia (UI-Press).

\section{Jurnal dan Artikel IImiah}

Arisman. 2009. "Menakar Maslahat Operasi Kelamin Perspektif Hukum Islam". Hukum Islam. Vol XIX No. 1, Pekanbaru: Univeritas Islam Negeri Sultan Syarif Kasim.

Gibtiah. 2014. "Studi Perbandingan tentang Khunsa dengan Transseksual dan Transgender (Telaah Pemikiran Ulama' Klasik dan Ulama' Modern)". Jurnal Intizar. Vol. 20, No. 2. Palembang : Universitas Islam Negeri Raden Fatah Palembang.

Risdalina. 2016. "Kedudukan Hukum terhadap Status Perubahan Jenis Kelamin dalam perspektif Hak Azasi Manusia dan Administrasi Kependudukan”. Jurnal IImiah “Advokasi. Vol. 04. No. 02. Labuhanbatu: Sekolah Tinggi Ilmu Hukum.

Sjanette Eveline. 2019. "Transgender dalam Perspektif Teologis Alkitabiah". Jurnal Teologi dan Pendidikan Kristen. Vol. 1 No. 1. Juni 2019. Surabaya: Sekolah Tinggi Teologi Adhi Wacana Surabaya.

Syafi'in Mansur. 2017. "Homoseksual dalam Perspektif Agama-Agama di Indonesia”. Aqlania, Vol. 08. No. 01 (Januari-Juni) 2017. Banten: IAIN Sultan Maulana Hasanuddin Banten.

Tomislav Bracanovic. 2016. "Sex Reassignment Surgery and Enhancement". The Journal of Medicine and Philosophy. Volume 42, Issue 1. Zagreb: University of Zagreb.

Zenny Natasia Lianto, 2018. "Akibat Hukum Operasi Ganti Kelamin terhadap Keabsahan Perkawinan”. Arena Hukum. Vol. 11 No. 2. Agustus 2018. Surabaya: Universitas Airlangga. 